\title{
Bizonyítékokon alapuló egészségpolitikai döntéshozatal az integrált ellátásban
}

\author{
A Ritka Betegségek Nemzeti Erôforrás Központjának \\ tervezési folyamata
}

\author{
Pogány Gábor dr. ${ }^{1}$ - Csanádi Marcell dr. ${ }^{2}$ - Pitter János György dr. ${ }^{2}$ \\ Zemplényi Antal Tamás dr. ${ }^{2,3}$. Bódy Éva ${ }^{4}$ \\ Bojtor Zsuzsanna ${ }^{1}$. Kereki Judit dr. ${ }^{5}$. Fadgyas-Freyler Petra dr. ${ }^{6}$ \\ Szabó Lajos dr. ${ }^{7}$. Kaló Zoltán dr. ${ }^{2,8}$ \\ ${ }^{1}$ Ritka és Veleszületett Rendellenességgel Élők Országos Szövetsége, Budapest \\ ${ }^{2}$ Syreon Kutató Intézet, Budapest \\ ${ }^{3}$ Pécsi Tudományegyetem, Gyógyszertudományi Kar, Pécs \\ ${ }^{4}$ Semmelweis Egyetem, Egészségügyi Menedzserképző Központ, Budapest \\ ${ }^{5}$ Eötvös Loránd Tudományegyetem, Bárczi Gusztáv Gyógypedagógiai Kar, \\ Általános Gyógypedagógiai Intézet és Atipikus Viselkedés és Kogníció Gyógypedagógiai Intézet, Budapest \\ ${ }^{6}$ Nemzeti Egészségbiztosítási Alapkezelő, Budapest \\ ${ }^{7}$ Eötvös Loránd Tudományegyetem, Társadalomtudományi Kar, Szociális Munka Tanszék, Budapest \\ ${ }^{8}$ Semmelweis Egyetem, Egészségügyi Technológiaértékelő és Elemzési Központ, Budapest
}

Bevezetés: A ritka betegséggel élők ellátásában fontos előrelépések történtek az elmúlt években. Egy következő lépés lehetne hazánkban a Ritka Betegségek Nemzeti Erőforrás (Uni-Versum) Központjának (a továbbiakban: Központ) létrehozása, amely az egészségügyi, szociális és köznevelési szolgáltatásokat összehangolva és kiegészítve személyközpontú ellátást nyújtana a betegek és támogatóik részére.

Célkitüzés: Célunk az volt, hogy egy nemzetközi tudományos módszertan alapján javaslatokat tegyünk arra, hogy milyen eszközökkel lehet feloldani a Központ megvalósításának lehetséges korlátozó tényezőit.

Módszer: A Központ megvalósíthatóságának értékelésére interdiszciplináris szakmai egyeztetést szerveztünk különböző érintett érdekcsoportok részvételével, a SELFIE H2020 kutatási projekt által kidolgozott módszertan alapján. Az előzetesen rangsorolt legfontosabb korlátozó tényezőkre lehetséges megoldási javaslatokat tettünk.

Eredmények: A lehetséges korlátozó tényezőket a résztvevők relevánsnak tartották a Központ létrehozásával kapcsolatban, és ezekre összesen 17 olyan konkrét javaslat született, amelyben a résztvevők között egyetértés alakult ki. A javaslatok kiterjedtek az ellátás tartalmára, az alkalmazott technológiák támogató szerepére, a humánerőforrás-korlátok megoldására, a hatékony vezetés és szervezés kialakítására, az összetett finanszírozási struktúra kialakítására és a kutatási lehetőségek megteremtésére is.

Megbeszélés: A Központ megvalósítása esetén a ritka betegséggel élők ellátása az egészségügyi, szociális és köznevelési tevékenységeket integráló megközelítés felé mozdulna el. A kutatás során megfogalmazott javaslatok hozzájárulhatnak a Központ létrehozásához, amennyiben megvan az ehhez szükséges szakpolitikai támogatás is. Ezen túlmutatóan, a leírt munkamódszer más integrált ellátási modellek bevezethetőségének elemzéséhez is mintaként szolgálhat. Következtetés: Összefoglalva megállapíthatjuk, hogy a Központ létrehozásához számos, előzetesen is látható korlátozó tényezőt kell feloldani. Az érdekcsoportok közös javaslatai alapján kialakítható egy olyan múködési forma, amely az ellátórendszerek kiegészítésével és összehangolásával jelentős társadalmi értéktöbbletet eredményezhet.

Orv Hetil. 2021; 162(45): 1818-1825.

Kulcsszavak: ritka betegségek, integrált ellátás, betegútmenedzsment

\section{Implementation of evidence-based health policy in the field of integrated care}

\section{The planning process of the Hungarian National Resource Centre for Rare Diseases}

Introduction: In Hungary, significant achievements have been made in the care of patients with rare diseases in recent years. A next step could be the establishment of the National Resource Centre for Rare Diseases (hereinafter: Centre) to facilitate patient-centered complex care by the integration and supplementation of existing health, social and educational services. 
Objective: This research aimed to develop recommendations based on international scientific methodology to overcome potential implementation barriers of the aforementioned Centre.

Method: To evaluate the feasibility of the implementation, we organized an interdisciplinary workshop with representatives of different stakeholder groups, adopting the methodology developed in the SELFIE H2020 research project. During the workshop, we discussed the previously ranked, most significant implementation barriers and made recommendations for potential solutions.

Results: The potential implementation barriers were considered relevant by the participants and, reflecting on these barriers, altogether 17 recommendations were developed by consensus. These recommendations were related to the content of service delivery, use of supportive technologies, overcoming workforce issues, establishing effective leadership, implementing a complex financing structure and creating research opportunities.

Discussion: Implementation of the Centre would shift the care of rare diseases towards personalized and integrated health, social and educational services. Our recommendations will contribute to the establishment of the Centre, subject to positive policy decision. Furthermore, our methodological approach could support the feasibility assessment of future integrated care solutions and programs.

Conclusion: Several predictable barriers must be overcome to establish the Centre. Recommendations developed by representatives of relevant stakeholders could support successful implementation and societal value generation.

Keywords: rare diseases, integrated care, patient pathway management

Pogány G, Csanádi M, Pitter JGy, Zemplényi AT, Bódy É, Bojtor Zs, Kereki J, Fadgyas-Freyler P, Szabó L, Kaló Z. [Implementation of evidence-based health policy in the field of integrated care. The planning process of the Hungarian National Resource Centre for Rare Diseases]. Orv Hetil. 2021; 162(45): 1818-1825.

(Beérkezett: 2021. március 11.; elfogadva: 2021. április 29.)

\section{Rövidítések}

BNO = Betegségek Nemzetközi Osztályozása; RIROSZ = Ritka és Veleszületett Rendellenességgel Élők Országos Szövetsége; taj = társadalombiztosítási azonosító jel

A ritka betegségek jellemzően fokozatosan romló egészségi állapottal járó kórképek, amelyek tízezer lakosból legfeljebb ötöt érintenek. A gyakran nehezen felismerhetó betegségek a testi és szellemi képességek progresszív csökkenéséhez vezetnek, és akár korai halált is okozhatnak [1]. A ritka betegséggel élők számára számos egészségügyi és szociális probléma jellemzően súlyosabban jelenik meg a gyakori betegségekben szenvedőkhöz képest. Egyrészről a felismerésig és a pontos diagnózisig hosszabb idő telik el, valamint gyakoriak a tévesen diagnosztizált kórképek, amelyek indokolatlan kezelésekhez vezethetnek [2]. Másrészrôl a ritka betegségek többsége a helyes diagnózis birtokában sem gyógyítható, így a cél mindössze a betegek képességeinek, valamint életminőségének javítása vagy fenntartása lehet [3]. A ritka betegségek alapvetően változtatják meg a betegek és családtagjaik helyzetét, hiszen a diagnózis laikusként nehezen érthető meg, a kezeléssel járó bizonytalanság reményvesztettséghez vezethet, valamint az ellátás biztosítása anyagi nehézségekkel is járhat. Az érintettek szociális élete szintén megváltozik, és társadalmi kapcsolataik beszúkülnek [1]. A ritka betegségek betegségterhével, költségével, valamint az összetett finanszírozási kérdésekkel számos korábbi hazai tanulmány foglalkozott [4-7].
Az Európai Unió fontos népegészségügyi prioritásként kezeli a ritka betegségben szenvedő egyének jogainak és esélyegyenlőségének biztosítását. A tagállamok számára erre a célra nemzeti tervek és stratégiák kidolgozását és életbe léptetését ajánlotta [8]. Hazánkban a Ritka és Veleszületett Rendellenességgel Élók Országos Szövetsége (RIROSZ) civil szervezet és tagszervezetei ennek megfelelően túzték ki célul azt, hogy létrejöjjön egy ritka betegségekre vonatkozó Nemzeti Terv minden érintett (betegszervezetek, klinikusok, kutatók, gyógyszeripar és az egészségügyi kormányzat) bevonásával [3]. A Nemzeti Terv strukturált megközelítésmódot hivatott elősegíteni, amelynek célja, hogy a ritka betegségekkel kapcsolatos egészségügyi és szociális ráfordítások hatékonyan legyenek felhasználva. Az első, 2013-ban elfogadott Ritka Betegségek Nemzeti Terve 2020-ig szól, és kitér a szakemberek megfelelő képzésére, a szükséges diagnosztikus eszközökkel, személyi és technikai háttérrel rendelkező szakértői központok létrehozására és a racionalizált betegutak kialakítására is [9].

A Nemzeti Tervvel összhangban a ritka betegségek szakértői központjai is kialakultak hazánkban, amelyek a különböző ritka betegségek ellátásával foglalkozó gyógyítóintézményeket fogják össze, valamint csatlakoztak a ritka betegségek európai referenciahálózataihoz is. A hazai központok célja, hogy az érintett ellátóhelyek a betegek számára jobban láthatóvá váljanak, és segítsék az ellátóhelyek közötti betegutak folyamatosságának megszervezését. Az európai hálózat célja pedig a tagországok közötti ellátásbeli különbségek csökkentése a tapasztalatok és a tudás megosztásával [9], valamint a határokon 
átnyúló betegellátás megvalósításával [10]. Fontos eredmény hazánkban, hogy 2021-re vagy teljes jogú tagként, vagy affiliált partnerként minden európai referenciahálózathoz (összesen 24 hálózat) van magyar csatlakozás. A hálózatok részletes múködéséről külön tanulmányok számoltak be [11]. Szintén fontos fejlesztésnek tekinthető ezen a területen az elmúlt években múködtetett Mentőöv Információs Központ és Segélyvonal, amelynek célja, hogy a ritka betegséggel élők és környezetük hozzájusson szakszerü információkhoz.

A ritka betegséggel élők ellátásában egy következő, fontos továbblépés lehetne hazánkban a Ritka Betegségek Nemzeti Erőforrás (Uni-Versum) Központjának (a továbbiakban: Központ) létrehozása, amely „egyablakos”, személyközpontú ellátást nyújtana a ritka betegséggel élők és támogatóik részére a meglevő egészségügyi, szociális és köznevelési szolgáltatások kiegészítésére [12]. A javasolt Központ célja kielégíteni a ritka betegséggel élők azon igényét, hogy holisztikus szolgáltatásokat és támogatást kaphassanak, megkönnyítve a különböző szakmák és szakemberek együttmüködését a komplex és személyre szabott ellátási folyamatban [13]. Kiemelten fontos eleme a megvalósításnak az esetmenedzsment koncepciója, képzett intenzív esetmenedzserekkel. Az esetmenedzsment olyan, személyre szabott, együttmúködésre alapuló betegútszervező folyamat, amely kommunikációval és az erőforrások mozgósításával segíti a betegeket és hozzátartozóikat a teljes egészségügyi és szociális ellátás során. A folyamat során a támogatás egyénileg irányított, és magában foglalja az ellátás szakmai tartalmának tervezését és ütemezését, valamint monitorozását. Az intenzív esetmenedzseri tevékenység a betegség nyomán kialakuló, a beteget és az őt gondozó családot érintő pszichoszociális nehézségek komplex segítésében nyújtott hosszú távú és folyamatos támogatás. Ez a segítő munka hangsúlyosan támaszkodik a szociális szektorban mobilizálható forrásokra és támogató hátterekre, miközben strukturált keretek között kiterjed a beteg és a gondozó család megküzdési stratégiáinak és életviteli képességeinek megerősítésére és fejlesztésére. Ez a fajta esetvitel hosszú távú személyes kapcsolatot igényel a beteggel és családjával. Az esetmenedzser erre támaszkodva nagy esetviteli autonómiával rendelkezik, ugyanakkor ellátási koordinátorként hídszerepet játszik a család és a gyógyítóteam között. Mindez azt feltételezi, hogy az intenzív esetmenedzselés feladatait ellátó szakember megfelelő szakmai felkészültséggel rendelkező - a nemzetközi gyakorlatban elsősorban kvalifikált, posztgraduális programban felkészített - szociális munkás, akinek munkája megfelelő esetviteli kompetenciára és a társszakmákra való együttmúködési képességre épül.

Európában számos hasonló kezdeményezés jött létre az elmúlt években [14], mindegyik azzal a céllal, hogy információs és koordinációs csomópontot hozzon létre az egészségügyi és szociális ellátási, kutatási és oktatási területek között. Néhány erőforrásközponttal mélyreha- tóan foglalkozott a 2015 és 2018 között megvalósult INNOVCare kutatási program [15]. Ennek keretében részletesen bemutatták a Romániában megvalósított, ritka betegséggel élők esetmenedzselésére fókuszáló programot [16], valamint értékelték annak eredményességét az értékelésbe bevont 120 beteg többdimenziós szempontrendszere alapján [17]. A Központ megvalósítása elsősorban a társadalmi és szociális tényezők szempontjából bírt jelentős és mérhető előnyökkel a páciensek számára. Az integrált ellátás betegcentrikusabbá vált, a páciensek informáltabbak és tudatosabbak lettek a betegségükkel kapcsolatos teendőkben.

Annak érdekében, hogy a hazai Központ megfelelően illeszkedjen a magyarországi egészségügyi és szociális ágazat rendszerébe, szükséges átfogóan megvizsgálni a modell bevezetését befolyásoló tényezőket. A jelen kutatás célkitüzése az volt, hogy különböző szektorokból érkező szakemberek bevonásával, nemzetközi tudományos módszertan alapján javaslatokat tegyünk arra, hogy milyen eszközökkel lehet feloldani a Központ megvalósításának lehetséges korlátozó tényezőit.

\section{Módszer}

A Központ megvalósításának értékelésére és támogatására interdiszciplináris szakmai egyeztetést szerveztünk különböző érintett érdekcsoportok részvételével, a SELFIE Horizon 2020, európai uniós finanszírozású nemzetközi kutatási projekt keretein belül. A SELFIE Horizon 2020 konzorcium a krónikus multimorbid betegek több egészségügyi és szociális szolgáltató együttmúködésével megvalósuló integrált ellátási modelljeit vizsgálta Európa nyolc országában [18]. Hazánkban két, már meglévő ellátási modellkísérlet esetén végeztünk részletes elemzéseket [19, 20]. Ugyanakkor a projekt keretein belül arra is kísérletet tettünk, hogy egy, hazánkban még meg nem valósult, de nemzetközi példák alapján létrehozható speciális ellátási program implementációjának a kérdését vizsgáljuk.

A szakmai egyeztetés témáit a SELFIE Transzferabilitás kérdőív alapján határoztuk meg. Az ennek alapjául szolgáló kutatás célja az volt, hogy felmérje a különböző, szektorokon átnyúló, integrált ellátási modellek bevezetését akadályozó vagy korlátozó tényezőket. A kutatás során online kérdőívet fejlesztettünk ki, amelynek keretében 5 közép-kelet-európai ország szakértői (Horvátország, Lengyelország, Magyarország, Románia és Szerbia) rangsorolták a lehetséges korlátozó tényezőket. A kérdőívvel kapcsolatos további módszertani részletek és a kutatás eredményei külön tanulmányban kerültek leírásra [21]. A magyarországi szakértők kérdőíveredményei alapján választottuk ki azt a legfontosabb 10 korlátozó tényezőt, amelyet a szakmai egyeztetés keretein belül részletesen megvitattunk. Ezeket a SELFIE konzorcium által kialakított szempontrendszer alapján [18] az alábbiak szerint rendeztük: 
- Az ellátás tartalmi szempontjai: 1) Az egészségügyi és szociális szektor közti integráció megvalósítása az ellátásban; 2) A szolgáltatók hozzáadott értékének mérése, minőségbiztosítás és finanszírozás céljából.

- Az alkalmazott technológiák szempontjai: 3 ) A betegek által használt eHealth és mHealth technológiák integrációja az ellátási folyamatba.

- A humáneröforrás szempontjai: 4) Elegendő egészségügyi és más ágazatokhoz tartozó szakdolgozó az ellátás megvalósításához; 5) Elegendő orvos és egyéb szakértő az ellátás megvalósításához; 6) Az új szakmai szerepek és felelősségek kölcsönös elfogadása.

- A vezetés és szervezés szempontjai: 7) Az együttmúködés és a kommunikáció kultúrája az egészségügyi és a szociális ellátók között.

- A finanszirozás szempontjai: 8) Az ellátás hosszú távú finanszírozása; 9) Az ellátás nemzeti vagy területi/önkormányzati szintű finanszírozása.

- Értékelési és kutatási szempontok: 10) Megfelelő kutatói kapacitás és tudás az ellátás teljesítményének rendszeres értékelésére.

A szakmai egyeztetés során a fenti témákat vitattuk meg az alábbi kérdések mentén: 1) Releváns-e az adott korlátozó tényező a Központ bevezetése kapcsán? 2) Ha igen, akkor mennyiben korlátozza a Központ megvalósítását? 3) Milyen konkrét javaslatok jöhetnek szóba a probléma megoldására a Központ bevezetésével kapcsolatban?
Az eseményt 2019. május 14-én rendeztük meg a Semmelweis Egyetem Gyógyszerésztudományi Karának tárgyalójában. Összesen 20 fó vett részt, a résztvevők 5 fó érintett csoportba sorolhatók: betegszervezetek képviselői: 7 fö; egyetemi kutatóközpontok képviselői: 5 fö; egészségügyi és szociálpolitikai közintézmények képviselői: 4 fő; finanszírozó szervezet képviselői: 2 fö; orvosszakmai terület képviselői: 2 fö.

Az egyeztetés keretein belül elhangzott javaslatokat és egyéb információkat a SELFIE-munkacsoport három kutatója egymástól függetlenül jegyzetelte. Az esemény után az információkat szintetizáltuk és megvitattuk. A jegyzetek összefoglalóját a javaslatokkal együtt elküldtük a résztvevőknek véleményezésre, majd a visszajelzések alapján véglegesítettük. A jelen közleményben a közösen véglegesített javaslatokat és véleményeket teszszük közzé.

\section{Eredmények}

A szakmai egyeztetés keretein belül felvetett 10 korlátozó tényezőt mind relevánsnak tekintették a résztvevők a Központ létrehozása kapcsán, és úgy vélték, hogy mindegyikre célzott javaslat megfogalmazása szükséges, hiszen ezek nélkül a jelenlegi egészségügyi, egyéb ágazati rendszereken belül nem képzelhető el a megvalósítás. A jelen közleményben arra törekszünk, hogy a problémákra olyan javaslatokat mutassunk be, amelyek az

1. táblázat | A kutatás során vizsgált korlátozó tényező́k és a hozzájuk tartozó javaslatok rövid összefoglalója

\begin{tabular}{|c|c|}
\hline Szempontok - Korlátozó tényezök & A javaslatok rövid összefoglalója \\
\hline $\begin{array}{l}\text { Az ellátás tartalmi szempontjai: } \\
\text { 1) Az egészségügyi, szociális és oktatásügyi szektor közti integráció } \\
\text { megvalósítása az ellátásban } \\
\text { 2) A szolgáltatók hozzáadott értékének mérése, minőségbiztosítás/ } \\
\text { finanszírozás céljából }\end{array}$ & $\begin{array}{l}\text { - A Nemzeti Erőforrás Központ múködési koncepciójának pontos } \\
\text { meghatározása } \\
\text { - Az integráció formalizálását segítő feltételek megteremtése } \\
\text { - A Központban múködó interdiszciplináris team teljesítményének } \\
\text { mérése az egyéni ellátási terv megvalósulása alapján }\end{array}$ \\
\hline $\begin{array}{l}\text { Az alkalmazott technológiák szempontjai: } \\
\text { 3) A betegek által használt eHealth és mHealth technológiák } \\
\text { integrációja az ellátási folyamatba }\end{array}$ & $\begin{array}{l}\text { - A betegek által használt eHealth és mHealth technológiák validálása } \\
\text { és terjesztése } \\
\text { - Standardizált adatgyújtés tervezése és kialakítása (az adatvédelmi } \\
\text { szabályozás figyelembevételével) }\end{array}$ \\
\hline $\begin{array}{l}\text { A humánerőforrás szempontjai: } \\
\text { 4) Elegendó egészségügyi és más ágazatokhoz tartozó szakdolgozó az } \\
\text { ellátás megvalósításához } \\
\text { 5) Elegendő orvos és egyéb szakértő az ellátás megvalósításához } \\
\text { 6) Az új szakmai szerepek és felelősségek kölcsönös elfogadása }\end{array}$ & $\begin{array}{l}\text { - Esetmenedzserek és egyéb szakemberek képzése és alkalmazása, } \\
\text { versenyképes javadalmazása } \\
\text { - Az esetmenedzser és az ellátásban részt vevő szolgáltatók kompe- } \\
\text { tenciahatárainak pontos leírása és elfogadtatása } \\
\text { - Az érintett családtagok bevonása a beteg integrált ellátásába } \\
\text { - A betegtársak és családtagok bevonása új betegek ellátásába }\end{array}$ \\
\hline $\begin{array}{l}\text { A vezetés és szervezés szempontjai: } \\
\text { 7) Az együttmúködés és a kommunikáció kultúrája az egészségügyi és } \\
\text { a szociális ellátók között }\end{array}$ & $\begin{array}{l}\text { - A bizalom javítása az integrált ellátás szereplői között } \\
\text { - A kommunikáció javítása az integrált ellátás résztvevőivel } \\
\text { - Az érintett intézmények vezetőinek elköteleződése az integrált } \\
\text { ellátás megvalósítására }\end{array}$ \\
\hline $\begin{array}{l}\text { A finanszírozás szempontjai: } \\
\text { 8) Az integrált ellátás hosszú távú finanszírozása (a kezdeti finanszíro- } \\
\text { zást követően) } \\
\text { 9) Az integrált ellátás nemzeti vagy területi/önkormányzati szintú } \\
\text { finanszírozása }\end{array}$ & $\begin{array}{l}\text { - A program indulási költségeinek fedezete } \\
\text { - A múködés fedezete kiszámítható finanszírozásra épüljön } \\
\text { - A fenntarthatóságot elősegítő további célzott finanszírozási elemek } \\
\text { bevonása }\end{array}$ \\
\hline $\begin{array}{l}\text { Értékelési és kutatási szempontok: } \\
\text { 10) Megfelelő kutatói kapacitás és tudás az integrált ellátás teljesítmé- } \\
\text { nyének rendszeres értékelésére }\end{array}$ & $\begin{array}{l}\text { - A kutatási kapacitás megteremtése } \\
\text { - Az adatok elérhetőségének biztosítása kutatási célokra }\end{array}$ \\
\hline
\end{tabular}


egyeztetésen jelen lévő érintett csoportok véleménye alapján megvalósíthatók. A javaslatokat a korábban megnevezett hat szempont mentén mutatjuk be. A javaslatok rövid összefoglalóját az 1 . táblázat tartalmazza.

\section{Javaslatok az ellátás tartalmi szempontjaira}

A Központ múködési kereteit pontosan meg kell határozni. Célszerü ennek kapcsán rugalmas múködést biztosító szervezeti formát definiálni (például civil szervezet vagy egyesület), amely könnyen alakít ki együttmúködést az állami szférán túl más szervezetekkel is (például egyházi szervezetekkel, civil szervezetekkel vagy gazdasági társaságokkal). Fontos, hogy a szociális és egészségügyi szektor szereplői a kezdetektől fogva részt vegyenek a múködési feltételrendszer kialakításában, hogy a különböző szektorok speciális jellemzőit figyelembe lehessen venni. Ennek megfelelően az egészségügyi és a szociális szolgáltatási szektort érintő, integrált múködést kell kialakítani. Ugyanakkor a betegek jellemző életkora miatt a köznevelési szektort is érdemes bevonni a közös keretek kialakításába, hiszen a ritka betegséggel élők igényei alapján a speciális köznevelési feltételek megteremtését is gyakran ki kell alakítani. Mindehhez az intenzív esetmenedzselési modell bevezetése szükséges, amelynek kiindulási alapja a betegek kockázatfelmérése az ellátási igény meghatározásához, majd az egyéni ellátási terv definiálása.

A Központban létrehozott interdiszciplináris csapat teljesítménymérésének rendszerét az egyéni ellátási terv megvalósulása alapján szükséges kidolgozni. Ehhez elengedhetetlen, hogy a szektorok előzetesen és együttesen állapodjanak meg abban, hogy az interdiszciplináris team által nyújtott egészségügyi, szociális és pedagógiai ellátási elemek milyen szerepet játszanak a beteg terveiben, és ezek hogyan viszonyulnak egymáshoz. Az egyéni ellátási terv létrehozását követően a megvalósítás betegszintű monitorozása is szükséges.

Ezen túl meg kell teremteni az integráció formalizálását segítő feltételeket is. Technikai szempontból lényeges, hogy melyik az a közös egyedi személyi azonosító kód, amely minden érintett szektor részéről kezelhető és használható az ellátás során (ahogy a tajszám az egészségügyi és szociális ellátásban). Az ellátást dokumentáló informatikai rendszerek közötti kommunikáció elengedhetetlen, végül pedig nagy hangsúlyt kell fektetni arra is, hogy ne legyen szükség párhuzamos dokumentálásra a szektorokon átívelő szolgáltatások esetén.

\section{Javaslatok az alkalmazott technológiák szempontjaira}

Az alkalmazott technológiákkal kapcsolatban elsősorban a betegek által használt, elektronikusan elérhető egészségügyi szolgáltatások és technológiák (a továbbiakban: eHealth), valamint ezen belül a mobil eszközökkel hasz- nálható szolgáltatások és technológiák (a továbbiakban: mHealth) validálásának és terjesztésének igénye merült fel. Fel kell térképezni és azonosítani kell a megbízható és a ritka betegséggel élők szempontjából hasznos technológiákat, amelyeket a betegek között széles körben lehetne terjeszteni. Ez azt a célt is szolgálja, hogy minél több beteget lehessen elérni, és minél többen tartsák a kapcsolatot a Központtal. A hozzáférés javítása mellett a betegirányítás és a szolgáltatásszervezés érdekében is célszerű olyan eHealth-eszközöket és mHealth-technológiákat bevonni az ellátásba, amelyek az egészségügyi és szociális szektor számára hasznosak, közvetlenül a betegtől származó információkat gyưjjtenek. Ehhez családtagok aktív bevonása és oktatása is nélkülözhetetlen.

Az ellátás támogatása érdekében szükséges a standardizált adatgyújtés megtervezése és kialakítása. Ezt támogatná egy közös, ritka betegségekre fókuszáló betegségregiszter fejlesztése és a már meglévő ilyen jellegü regiszterek összekapcsolása. Az új regiszter a Központban bármely speciális ritka betegség kórképével diagnosztizált beteg ellátásához támogatást tud adni. Ki kell alakítani egy felhasználóbarát platformot a beteg és a családtagok által közvetlenül szolgáltatott adatok számára. Az adatvédelmi aggályok eloszlatása érdekében külön figyelmet kell szentelni a betegtájékoztatásra és az adatok megosztásáról szóló hozzájárulás biztosítására. A szigorú adatvédelmi előírások kialakítása és betartása alapvető feltétel az eHealth és mHealth rendszerszintú alkalmazásához. Ennek következtében létfontosságú az adatvédelmi jog megfelelő ismerete és egy annak megfelelő adatvédelmi szabályzat kialakítása is.

\section{Javaslatok a humáneröforrás szempontjaira}

Megkerülhetetlen az ellátásban részt vevő különböző szolgáltatók kompetenciahatárainak pontos leírása és elfogadtatása. Ehhez szükséges az egészségügy, a szociális és oktatásügy irányaiba a kompetenciatérképek meghatározása, összehangolása, majd kommunikációja. A kompetenciák meghatározásakor az ágazatok közötti folyamatokat egyértelmúen kell rögzíteni. Ehhez a javaslathoz szorosan kapcsolódik az intenzív esetmenedzseri pozíció kialakítása, az átfogó képzés megszervezése és a működtetéshez szükséges létszám felmérése. A képzés során fontos lenne a hazai egyetemi ritkabetegség-központok és az egészségügyimenedzsment-képzést nyújtó helyek bevonása. Célszerú lenne továbbá, ha az esetmenedzserek koordinációs csoportokat alakítanának ki annak érdekében, hogy hatékonyan segítsék az ellátásban részt vevők munkáját, és speciális kompetenciáikat egymás között megosszák.

A Központnak külön tervet kell készítenie arra, hogy minél hatékonyabban tudja bevonni az érintett családtagokat a betegellátási folyamatba. Egyrészról ehhez elengedhetetlen a családtagok és az ellátást végző különböző szakemberek közötti jó kapcsolat, az ehhez szükséges hatékony kommunikációt az esetmenedzser segítheti. 
Másrészről biztosítani kell az ellátásban részt venni kívánók számára a képzési lehetőségeket. Harmadrészt pedig lehetőséget kell adni arra, hogy a családtagok meg tudják osztani egymással hasznos mindennapi tapasztalataikat. Ehhez kapcsolódóan a humáneróforrás-gondokat enyhíteni lehetne azzal, ha betegtársakat és családtagokat be lehetne vonni más betegek ellátásának szervezésébe is. A betegek és a családtagok közötti empátiára alapozva - egymás támogatásához - egy formálisabb keretrendszert is ki lehet alakítani (például tudásátadás mentorprogramon keresztül). Meg kell teremteni a gyakorlati tanácsok megosztásának fórumát is, lehetőleg mind a virtuális térben, mind pedig személyes találkozások keretében. Végezetül pedig azon családtagok, akik idővel megfelelő képzettséget kapnak, és hatékonyan tudják átadni tapasztalataikat, akár formális szerepet is vállalhatnak a Központban (például esetmenedzserré válhatnának).

\section{Javaslatok a vezetés és szervezés szempontjaira}

Az egyeztetés résztvevőinek véleménye szerint a vezetés és szervezés szempontjából a legfontosabb kérdés a bizalom javítása a ritka betegségek ellátását biztosító, különböző szektorokban múködő szereplők között. Ahhoz, hogy a bizalom fejlődhessen, a terápiás célokat és az ellátási terveket minden érintett szektor bevonásával közösen kell kialakítani, és minél több személyes kapcsolatot kell létrehozni az ellátásban részt vevők között. Ennek egyik gyakorlati megvalósulása lehet a közös képzéseken való részvétel és a koordinációs csoportban történő együttes aktív részvétel az esetmenedzser irányításával. A szereplők közötti hatékony kommunikáció közös esetmegbeszélések alkalmával tud megvalósulni, ehhez olyan környezetet kell biztosítani, ahol törekedni tudnak a közös nyelv kialakítására és a különböző szakmákban előforduló szakzsargonok kölcsönös megtanulására.

A Központ és a Központtal együttmúködő intézmények kapcsán szükség van az illetékes intézmények vezetői részéről elköteleződésre az integrált ellátás megvalósítására. A Központ szakmai vezetőségében szükség van olyan szakemberekre, akik az integrált ellátás szemléletét megfelelően tudják képviselni. Továbbá javaslatként fogalmazódott meg, hogy a Központ szakmai vezetésén kívül célszerü lenne egy tanácsadó testület létrehozása is. Ez lehetőséget adna arra, hogy különböző ellátási szektorokból és különböző szintekről érkező személyeket lehessen bevonni (például minisztériumokból, egyetemekről, önkormányzatból), illetve lehetőséget teremtene arra, hogy szakmai kollégiumi tagozatok, valamint orvosi és egészségügyi szakmai tudományos társaságok irányában aktív kapcsolat jöjjön létre.

\section{Javaslatok a finanszírozás szempontjaira}

Finanszírozási szempontból az első fontos megoldandó kérdés a Központ indulási költségeinek fedezete. Ehhez hazai és európai uniós forrás is bevonható. A célzott fi- nanszírozásnak három fó területet kell lefednie: infrastruktúra kialakítása, az esetmenedzseri képzés kezdeti költségeinek fedezése, valamint a bérköltségek átmeneti célzott finanszírozása.

Ezek után második lépésként elengedhetetlen, hogy a múködési költségek fedezete biztosítva legyen, ehhez hosszú távú, kiszámítható finanszírozás szükséges. El kell érni azt, hogy egy új finanszírozási tétel legyen kialakítva az esetmenedzseri tevékenységhez (például fejkvótaalapú finanszírozás + interdiszciplináris esetmegbeszélés finanszírozása, például betegenként havonta egyszer jelenthető kóddal). Ezt kiegészítve a Központban megjelenhetnek részben államilag támogatott szolgáltatások is (például gyógypedagógia, gyógytornász, pszichológia, speciális oktatási igények kielégítését célzó tevékenységek). Szintén javaslatként merült fel, hogy az esetmenedzserek munkaidejét és tevékenységeit - például félállások formájában - úgy lehessen megosztani, hogy több szektorból is kaphassanak finanszírozást (például az egészségügyi szektorból a dietetikusi tanácsadásért és a szociális szektorból a szociális munkáért).

A fenntarthatóság érdekében további célzott finanszírozási elemek bevonása is szükséges lehet. Ilyen források lehetnek az önkormányzati támogatások, a kutatási források bevonzása (például európai uniós pályázatok vagy gyógyszeripari kutatások), a kapcsolódó magánszolgáltatások bevételei (például konferenciaterem, kávéház, játszóház, uszoda bérbeadása), egyházi támogatások (például köznevelési célú támogatás) és a háztartások önkéntes hozzájárulásai. Szerencsés lenne, ha ezek a források nem a múködési költségek fedezetéül szolgálnának, hanem a fejlődést segítő, kiegészítő programok költségeit fedeznék.

\section{Javaslatok az értékelési és kutatási szempontokra}

A Központ hosszú távú hatékony múködéséhez fontos a kutatási kapacitás megteremtése, ebben segíthet az állandó együttmúködés kialakítása az egyetemek kapcsolódó képzéseivel és doktori iskolákkal. A Központnak nyitottnak kell lennie kutatók fogadására, és képesnek kell lennie érdemben támogatni a kutatásokat. Ezenfelül célszerü együttmúködnie más, a ritka betegségekkel foglalkozó hazai és nemzetközi kutatói hálózatokkal is. A Központ a regiszterekben gyújtött adatokból kutatási célú adatvagyont alakíthat ki, melynek felhasználásához meg kell teremteni a megfelelő jogi szabályozást. Célszerü lenne strukturált adatgyüjtési környezetet létrehozni, valamint biztosítani az adatok megfelelő anonimizálását is. Végezetül gondoskodni kell arról, hogy a betegek hozzájáruljanak az adatok kutatási célú felhasználásához.

\section{Megbeszélés}

Magyarország első Ritka Betegségek Nemzeti Terve 2020 végén lejárt, és jelenleg napirenden van a második Ritka Betegségek Nemzeti Tervének kialakítása. 
A RIROSZ alapvető céljának tekinti, hogy az első Nemzeti Tervben dominánsan megjelenő orvosszakmai nézőpont a következő tervezési időszakban elmozduljon a szociális, köznevelési, családügyi és munkaügyi ellátásokat is hangsúlyosan kezelő és integráló, kiegyensúlyozottabb megközelítés felé. A Központ létrehozása éppen ezt a célt támogatja. A SELFIE Horizon 2020 konzorcium hazai partnere által szervezett szakmai egyeztetésen kialakított és megvitatott javaslatok közzététele hozzájárulhat a Központ létrehozásának tervezéséhez. Amenynyiben megvan az ehhez szükséges szakpolitikai szándék és támogatás, a Központ megvalósítására és múködtetésére vonatkozó, itt leírt javaslatok helyet kaphatnak a második Ritka Betegségek Nemzeti Tervének célkitüzései között. Ezen túlmutatóan, a leírt munkamódszer más integrált ellátási modellek bevezethetőségének elemzéséhez is mintaként szolgálhat. A bemutatott módszertan ötvözi a nemzetközi szakirodalomban és a SELFIE-projektben kikristályosodott tudásanyagot az integrált ellátási modellek keretrendszeréról, összetevőiről és értékeléséről. Ehhez szükséges az érintett szakmai csoportok egy asztalhoz ültetése és konstruktív együtt gondolkodása.

Annak érdekében, hogy a Központ kialakításához minél több szempontból tudjunk javaslatokat megfogalmazni, a jelen kutatás keretein belül egy nemzetközi keretrendszert követtünk, amely az integrált ellátási programok értékelését hivatott elősegíteni [18]. Bemutatott tanulmányunk nemzetközi terminológiával élve transzferabilitási elemzésként is értelmezhető. Az integrált ellátási programok transzferabilitásának értékelése során azt kell strukturált keretek között megvizsgálni, hogy egy más országban/régióban múködő programot be lehet-e vezetni adott helyi keretek között, és ha igen, akkor azt hogyan érdemes megvalósítani. A transzferabilitás vizsgálatának kérdése Közép-Kelet-Európa országaiban kiemelten fontos, hiszen egy máshol (például Nyugat-Európában) jól múködő program bevezetése kevesebb ráfordítással megvalósulhat, mint egy új program kialakítása, az egészségügyi rendszer szempontjából. Ehhez viszont elengedhetetlen a transzferabilitás vizsgálata. Ehhez a SELFIE hazai munkacsoportja részletes útmutatót alakított ki [22], melynek első lépéseit végeztük el: 1) a korlátozó tényezók azonosítása, majd 2) a korlátozó tényezők priorizálása az adott program szempontjából; 3) a korlátozó tényezők feloldására vonatkozó javaslatok megfogalmazása különböző érintett érdekcsoportok véleménye alapján.

Tanulmányunk az elméleti alapokon kívül konkrét gyakorlati tanácsokkal is szolgált a Központ létesítéséhez. Fontos megjegyezni azonban, hogy nem képezte a kutatás tárgyát az, hogy a Központ hogyan illeszkedjen be a döntéshozatali struktúrába, milyen betegkörre fókuszáljon, és mekkora költségvetéssel múködjön. Ezek olyan fontos kérdések, melyeket a Központ létrehozásához szükséges megvalósíthatósági tanulmánynak kell taglalnia. A fenti eredmények szintén lökést adtak egy ágazatközi operatív bizottság felállításához, melyben az érintett államtitkárságok (Egészségügyi, Szociális, Köznevelési, Családügyi, valamint a Felsőoktatásért, Innovációért és Szakképzésért Felelős Államtitkárság) képviselői a létesítésben részt vevő szervezetekkel közösen foglalkoznak majd a felmerülő operatív kérdésekkel.

Összességében bízunk abban, hogy eredményeink közzététele hozzá tud járulni a Központ létrehozásához, amely megoldást tudna nyújtani az egyik legnagyobb, súlyos betegséggel és fogyatékkal élő csoportnak [23], a ritka betegséggel élőknek a legfontosabb problémáira: - Az ágazatközi információ és koordináció javításával a Központ elósegitheti az integrált ellátás megvalósulását, hiszen a tüneti kezelések gyors fejlődése ellenére sajnos napjainkban a ritka betegségek töredéke gyógyítható véglegesen, ezért a többség számára gyakran már csak az egészségügyön kiviuli többi ágazat képes az érintett családok életminőségén javítani, melyek számára sokszor új a ritka betegség fogalma.

- A Központ a betegek követésével, adatbázis építésével segithet a ritka betegségek „láthatatlanságának” gondján. A Magyarországon alkalmazott BNO-10-rendszerben csupán kb. 500 különböző ritka betegségnek van egyedi kódja, ezért a többi, sok ezer betegség statisztikája nem követhető, a finanszírozási rendszerek számára láthatatlan, akadályozva az optimális ellátásszervezést és döntéshozatalt [9].

- A Központ képes lehet az ágazati források felhasználásának hatékonyságát növelni a betegutak racionalizálásával, csökkentve a sokszor évtizedes diagnosztikai késedelmet és ezáltal a felesleges, duplikált kezelések mennyiségét [1]. Mindez mérsékelheti a családok mindennapi terheit is.

Anyagi támogatás: A közleményhez kapcsolódó kutatómunka anyagi támogatásban részesült az Európai Bizottság által finanszírozott SELFIE Horizon 2020 kutatási projekt keretein belül (a támogatási megállapodás azonosítója: \#634288). A Syreon Kutató Intézet munkatársai a SELFIE Horizon 2020 konzorcium tagjai voltak a 2015 és 2019 közötti időszakban.

Szerzői munkamegosztás: A kutatás koncepciójának kialakítása: Cs. M., P. J. Gy., Z. A. T., K. Z. A szakmai egyeztetés megszervezése: P. G., B. Zs., Cs. M., P. J. Gy., Z. A. T., K. Z. A szakmai egyeztetésen való részvétel: P. G., B. Zs., B. É., K. J., Cs. M., P. J. Gy., Z. A. T., F.-F. P., Sz. L., K. Z. A közlemény első verziójának elkészítése: Cs. M., P. J. Gy., Z. A. T., K. Z. A közlemény átnézése és javítása: P. G., B. Zs., B. É., K. J., F.-F. P., Sz. L. A közlemény végleges változatát valamennyi szerző elolvasta és jóváhagyta.

Érdekeltségek: A szerzőknek nincsenek érdekeltségeik. 


\section{Köszönetnyilvánítás}

A szerzők köszönetüket fejezik ki a SELFIE Horizon 2020 konzorcium minden tagjának, akik hozzájárultak a kutatási háttér megteremtéséhez. Köszönet illeti a közlemény hátterét adó szakmai egyeztetés résztvevőit a tapasztalatok megosztásáért és a konstruktív javaslatokért Név szerint, köszöneti illeti az alábbi résztvevőket, akik nem szerepelnek a jelen közlemény szerzői között: $d r$. Bagi Krisztina, Becskeházi Tar Judit, dr. Berencsi Andrea, Csieklinszki Zsanett, dr. Endrei Dóra, Jakab Ivett, dr. Márkus Eszter, dr. Radványi Katalin, Péteri János, dr. Schultheisz Judit, Simon Sára, Zalatnai Klára, dr. Zelei Tamás.

\section{Irodalom}

[1] Földvári A, Szy I, Sándor J, et al. Diagnostic delay of rare diseases in Europe and in Hungary. [A ritka betegségek diagnosztikájának késedelme Európában és Magyarországon.] Orv Hetil. 2012; 153: 1185-1190. [Hungarian]

[2] EURORDIS. The voice of 12,000 patients: experiences and expectations of rare disease patients on diagnosis and care in Europe. Available from: https://www.eurordis.org/IMG/pdf/ voice_12000_patients/EURORDISCARE_FULLBOOKr.pdf [accessed: March 1, 2021].

[3] Pogány G. Rare diseases and their patient organization: the Hungarian Federation of People with Rare and Congenital Diseases. [A ritka betegségek és hazai betegszervezetük - a Ritka és Veleszületett Rendellenességgel Élők Országos Szövetsége.] Orv Hetil. 2014; 155: 329-333. [Hungarian]

[4] Péntek M, Baji P, Pogány G, et al. Health related quality of life of patients and their caregivers in rare diseases results of the BURQOL-RD project in Hungary. Value Health 2014; 17: A538.

[5] Szegedi M, Kosztolányi G, Boncz I, et al. Financing of medicines for treatment of rare diseases of the nervous system. Orphan drugs in rare neurological diseases. [Ritka idegrendszeri betegségek kezelésére szolgáló gyógyszerek támogatása. Árva gyógyszerek ritka neurológiai kórképekben.] Ideggyogy Szle. 2016; 69: 37-45. [Hungarian]

[6] Szegedi M, Molnár MJ, Boncz I, et al. Shift of focus in the financing of Hungarian drugs. Reimbursement for orphan drugs for treating rare diseases: financing of enzyme replacement therapy in Hungary. [Hangsúlyeltolódások a hazai gyógyszerek finanszírozásában. A ritka betegségek kezelésére szolgáló árva gyógyszerek támogatása. Enzimpótló kezelések finanszírozása hazánkban.] Orv Hetil. 2014; 155: 1735-1741. [Hungarian]

[7] Szegedi M, Zelei T, Arickx F, et al. The European challenges of funding orphan medicinal products. Orphanet J Rare Dis. 2018; 13: 184 .

[8] EUCERD Joint Action. Report on the state of the art of rare disease activities in Europe. European Union, 2014. Available from: https://ec.europa.eu/health/sites/health/files/rare_diseases/docs/2014report_rare_disease_activitieseu_l_en.pdf [accessed: March 1, 2021].

[9] Pogány G. The actual questions of the care of rare diseases [A ritka betegségek ellátásának aktuális kérdései.] Orv Hetil. 2017; 158: 1851-1856. [Hungarian]

[10] Mönig I, Steenvoorden D, de Graaf JP, et al. CPMS-improving patient care in Europe via virtual case discussions. Endocrine $2021 ; 71: 549-554$
[11] Reinhard C, Bachoud-Lévi AC, Bäumer T, et al. The European reference network for rare neurological diseases. Front Neurol. 2021; 11: 616569 .

[12] EURORDIS. Policy fact sheet - resource centres for rare diseases. 2013. Available from: https://webgate.ec.europa.eu/ chafea_pdb/assets/files/pdb/20134309/20134309_d03-02oth-en-ps.pdf [accessed: March 1, 2021].

[13] McGarvey B, Hart C. An investigation into the social support needs of families who experience rare disorders on the island of Ireland. 2009. Available from: https://1stdirectory.co.uk/_assets/files_comp/b84fe2d6-5a59-4cfe-921f-8a7ddd46c7e9.pdf [accessed: March 1, 2021].

[14] EURORDIS. List of services. Available from: https://www.eurordis.org/de/content/resource-centres-list [accessed: March $1,2021]$

[15] INNOVCare. Bridging the gaps between health, social and local services to improve care of people living with rare and complex conditions. 2018. Available from: https://innovcare.eu/ wp-content/uploads/2018/01/INNOVCare-Project_Presentation.pdf [accessed: March 1, 2021].

[16] INNOVCare. Pilot of implementing case management for rare/ complex conditions in Sălaj County, Romania. 2018. Available from: https://innovcare.eu/wp-content/uploads/2018/12/ Report-Pilot-of-Implementing-Case-Management_INNOVCare.pdf [accessed: March 1, 2021].

[17] INNOVCare. WP7: evaluation report. The effects of a case management approach on the quality of life of rare disease patients in Sălaj, Romania: a pilot randomised control trial of efficacy. 2018. Available from: https://innovcare.eu/wp-content/uploads / 2018/12/INNOVCare_WP7_Evaluation-report_final-version. pdf [accessed: March 1, 2021].

[18] Leijten FR, Struckmann V, van Ginneken E, et al. The SELFIE framework for integrated care for multi-morbidity: development and description. Health Policy 2018; 122: 12-22.

[19] Pitter JG, Csanádi M, Szigeti A, et al. Planning, implementation and operation of a personalized patient management system for subjects with first suspect of cancer (OnkoNetwork): system description based on a qualitative study. BMC Health Serv Res. 2019; 19: 131

[20] Zemplényi AT, Csikós Á, Csanádi M, et al. Implementation of palliative care consult Service in Hungary - integration barriers and facilitators. BMC Palliat Care 2020; 19: 41.

[21] SELFIE Deliverable D7.1. Implementation strategies to CEE. Transferability of most promising ICC models, financial incentives, and performance monitoring to Central and Eastern Europe (CEE). 2019. Available from: https://ec.europa.eu/research/participants/documents/downloadPublic?documentIds =080166e5c708935f\&appId=PPGMS [accessed: March 1, $2021]$.

[22] Kaló Z, Zemplényi A, Rutten-van Mölken M, et al. Development of transferability guidance for integrated care models with special focus on Central and Eastern European countries. Croat Med J. 2020; 61: 252-259.

[23] Nguengang Wakap S, Lambert DM, Olry A, et al. Estimating cumulative point prevalence of rare diseases: analysis of the Orphanet database. Eur J Hum Genet. 2020; 28: 165-173.

(Zemplényi Antal dr., Pécs, Honvéd u. 3., 7624 e-mail: zemplenyi.antal@pte.hu)

A cikk a Creative Commons Attribution 4.0 International License (https://creativecommons.org/licenses/by/4.0/) feltételei szerint publikált Open Access közlemény, melynek szellemében a cikk bármilyen médiumban szabadon felhasználható, megosztható és újraközölhető, feltéve, hogy az eredeti szerző és a közlés helye, illetve a CC License linkje és az esetlegesen végrehajtott módosítások feltüntetésre kerülnek. (SID_1) 